\title{
Osmolyte modulated enhanced rice leaf catalase activity under salt-stress
}

\author{
Sushmita Sahu, Priyanka Das, Mamata Ray, Surendra Chandra Sabat* \\ Gene Function and Regulation Group, Stress Biology Laboratory, Institute of Life Sciences, Orissa, India. \\ Email: surendrachandra@gmail.com
}

Received 27 January 2010; revised 26 February 2010; accepted 8 March 2010.

\begin{abstract}
Change in catalase activity was examined in leaves of rice plant exposed to salinity. Depending on the method of preparation of crude protein extract from leaf and the constituents of the assay medium, a significant difference in enzyme activity was recorded. Inclusion of sorbitol or mannitol or sucrose in the extraction and enzyme assay medium enhanced the enzyme activity in salt-stressed samples by nearly 1.5-1.8 fold, compared to the activity found in unstressed plants, which otherwise showed a $50 \%$ declined activity in leaf extract prepared in buffer solution and assayed in a medium depleted of these sugars. In view of the accumulation of osmolytes under saline condition, these observations suggest that the catalase activity is modulated by the osmolytes and maintains a high rate of hydrogen peroxide scavenging property in vivo and serves as the major antioxidant enzyme to scavenge the salt-induced formation of peroxide. Therefore, the salt-stress induced appearance of low activity of the enzyme under normal buffer extraction and assay conditions, as reported in literature may represent an apparent than for its real in vivo activity.
\end{abstract}

Keywords: Catalase Activity; Hydrogen Peroxide; Osmolyte; Rice; Salt-Stress

\section{INTRODUCTION}

Salinity, comprising both osmotic and ionic effects is known to induce secondarily an oxidative stress in plants forming reactive oxygen species of various natures [1-3]. The reactive oxygen species (ROS) are highly cytotoxic and if remain un-scavenged, can react with vital biomolecules like protein, nucleic acid, lipids etc. causing an array of deformity to cell constituents [4]. Both non-enzymatic (tocopherol, ascorbic acid, glutathione etc.) and enzymatic (superoxide dismutase, ascorbate peroxidase, peroxidases, catalase etc.) antioxidant sys- tems operate through a complex networking machinery to avoid damage caused by these ROS [5]. Among the enzymatic antioxidants, superoxide dismutase (SOD) is the primary scavenger of ROS that dismutates superoxide anion $\left(\mathrm{O}_{2}^{-}\right)$to hydrogen peroxide $\left(\mathrm{H}_{2} \mathrm{O}_{2}\right)$ and water. A multiple enzyme systems like ascorbate peroxidase (APOX), peroxidases (POX) and catalase (CAT) further decomposes the $\mathrm{H}_{2} \mathrm{O}_{2}$. The CAT, as compared to APOX and $\mathrm{POX}$, with low affinity towards $\mathrm{H}_{2} \mathrm{O}_{2}$ but with a high processing rate [6], may become the principal enzymatic $\mathrm{H}_{2} \mathrm{O}_{2}$ scavenger in plants under salt-stressed conditions, where the cellular $\mathrm{H}_{2} \mathrm{O}_{2}$ level become several fold higher than found in plants grown under normal conditions $[1,7]$. This is essentially because, unlike other $\mathrm{H}_{2} \mathrm{O}_{2}$ scavenging enzymes (POX and APOX), CAT enzymatic reaction is not saturated with increasing concentrations of the peroxide and is independent of other cellular reductants for instituting its activity [6]. However, a large body of literature reports suggest that as compared to un-stressed plants the CAT activity is significantly down regulated in salt-stressed plants [8-14], suggesting that the enzyme may not serve as the major scavenger of $\mathrm{H}_{2} \mathrm{O}_{2}$ under salt offence to plants [13]. However, it is also suggested that maintenance of CAT activity could be a key factor for determining the stress tolerance in plants [12]. This bears importance particularly for $\mathrm{C}_{3}$ categories of plants like rice, where the photorespiratory activity is elevated under salt-stress [15]. The peroxisomal instituted elevation of photorespiratory activity may lead for higher accumulation of $\mathrm{H}_{2} \mathrm{O}_{2}$ as a result of conversion of glycolate to glyoxyate. Further, the peroxisome has been shown to be rapidly proliferated under oxidative stress [16]. Thus the CAT, principally a peroxisomal localized enzyme needs to operate effectively to eliminate the photorespiratory produced $\mathrm{H}_{2} \mathrm{O}_{2}$ [17].

Salt-stress also brings numerous metabolic changes in plant, the principal being the synthesis and accumulation of organic osmolytes [18-19]. Salt-induced accumulation of sugar alcohols like sorbitol, mannitol, inositol etc., or carbohydrates (sucrose, fructans etc.), and organic and 
amino acids like malate and proline, and many redoxregulating compounds such as glutathione, cystein and ascorbate and synthesis of LEA group of proteins have been documented in various plant species [20-21]. Metabolically engineered transgenics, leading for increase synthesis and accumulation of osmolytes of various natures have been shown to protect the plant against salinity stress [22-24]. It is presumed that while maintaining the cell turgor pressure in salt-stressed plants, the osmolytes also behave as osmo-protectants towards membrane-protein complexes and enzyme-proteins, and protect them from salt-induced impairments [25].

In the present investigation we found that supplementation of sugars or sugar alcohols like sucrose, sorbitol and mannitol in extraction and enzyme assay medium can sustain a significant high activity of CAT in rice plant, which otherwise showed a declined activity when exposed to saline environment. We put evidence that CAT in salt-stressed rice plant, as compared to the un-stressed one, is modulated by osmolytes in vivo, achieving a substantially high catalatic activity so as to serve as the major scavenger of $\mathrm{H}_{2} \mathrm{O}_{2}$.

\section{MATERIALS AND METHODS}

\subsection{Plant Material and Salt Treatment}

Seeds of Oryza sativa (Indica cultivar var. Ratna) were germinated on water soaked cotton pads for 72-h in dark at $25^{\circ} \mathrm{C}$. Seedlings were subsequently transferred for sand culture at $25^{\circ} \mathrm{C}$ under 12 -h photoperiod (light intensity $80 \mu \mathrm{Em}^{-2} \mathrm{~s}^{-1}$ ) and routinely irrigated with rice culture medium [26]. Ten days grown plants were further irrigated with rice culture medium containing $300 \mathrm{mM}$ $\mathrm{NaCl}$ for 4-d to develop salt-stress. The control set of plants were kept irrigated with normal rice culture medium.

\subsection{Spectrophotometric and In-Gel Assay of Catalase Activity}

The fully expanded secondary leaves (nearly $100 \mathrm{mg}$ fresh mass) were homogenized in $2 \mathrm{ml}$ ice cold $50 \mathrm{mM}$ $\mathrm{K}-\mathrm{PO}_{4}$ buffer ( $\mathrm{pH}$ 7.5) containing $0.1 \mathrm{mM}$ PMSF. The homogenate was centrifuged at $12,000 \mathrm{xg}$ for $10 \mathrm{~min}$ at $4^{\circ} \mathrm{C}$ and the supernatant was used for CAT activity assay. As when required, the leaf extract was prepared using the same extraction buffer containing required concentration of either mannitol or sorbitol or sucrose (see results).

Catalatic activity of the enzyme was monitored spectrophotometrically [27] by recording the decline of absorbance at $240 \mathrm{~nm}$ due to decomposition of $\mathrm{H}_{2} \mathrm{O}_{2}$ $\left(€=40 \mathrm{M}^{-1} \mathrm{~cm}^{-1}\right)$. For in-gel activity assay, the crude protein extract was first separated in $10 \%$ native PAGE at $4^{\circ} \mathrm{C}$ under constant current of $30 \mathrm{~mA}$ and the catalase activity in the gel was visualized through enzyme specific staining [28]. The protein concentration was measured following Bradford [29].

\subsection{Western Blot Analysis}

Catalase protein concentration in both control and salts-stressed leaf tissues were visualized through western blot analysis using rice catalase antibody, developed in rabbit (primary antibody). The Goat anti rabbit IgG horseradish peroxidase conjugate was used as secondary antibody. The PVDF membrane with transferred protein was treated with $\mathrm{H}_{2} \mathrm{O}_{2}$ and the protein bands were developed with $\mathrm{DAB}$ coloured reaction.

\subsection{Measurement of Glycolate Oxidase Activity}

Activity of glycolate oxidase (GO), an exclusively peroxisomal localized enzyme was measured following [30]. The leaf extract was prepared in $50 \mathrm{mM} \mathrm{K}-\mathrm{PO}_{4}$ buffer (pH 7.5) containing $1 \mathrm{mM}$ PMSF. The assay involves the measurement of the rate of formation of glyoxylate from glycolate in form of glyoxylate-phenylhydrazone. The reaction mixture in $1 \mathrm{ml}$ included $100 \mathrm{mM} \mathrm{K}-\mathrm{PO}_{4}$ buffer (pH 7.8), $6.5 \mathrm{mM}$ glycolic acid, $3.22 \mathrm{mM}$ cysteine, 3.22 $\mathrm{mM}$ phenylhydrazine, $0.03 \mathrm{mM}$ flavin-mononucleotide and $18 \mu \mathrm{g}$ protein equivalent leaf extracts as enzyme source. The quantification was made using $€$ of $17 \mathrm{mM}^{-1}$ $\mathrm{cm}^{-1}$ for glyoxylate-phenylhydrazone at $324 \mathrm{~nm}$.

Effect of sucrose in the enzymatic reaction GO was also determined as done for CAT.

\subsection{Estimation of Steady State $\mathrm{H}_{2} \mathrm{O}_{2}$ Level and NADH-Oxidase Activity}

Steady state level of $\mathrm{H}_{2} \mathrm{O}_{2}$ in leaves of control and salt-stressed plants were determined using FOX-1 method [31]. Leaves (100 $\mathrm{mg}$ fresh weight) were ground with $10 \%$ trichloro aceticacid and centrifuged at $12,000 \mathrm{xg}$ for $5 \mathrm{~min}$. The supernatant was passed through a bed of activated charcoal and a measured volume of filtrate was incubated with FOX-1 reagent (Ferrous oxidation with xylenol orange; $100 \mu \mathrm{M}$ xylenol orange, $250 \mu \mathrm{M}$ ammonium ferrous sulfate, 100 $\mathrm{mM}$ sorbitol, and $25 \mathrm{mM} \mathrm{H}_{2} \mathrm{SO}_{4}$ ) for $30 \mathrm{~min}$ (pre determined with standard $\mathrm{H}_{2} \mathrm{O}_{2}$ ) and absorbance was recorded at $560 \mathrm{~nm}$. The concentration of $\mathrm{H}_{2} \mathrm{O}_{2}$ was determined from a standard chart, obtained using 0.2-1 $\mu \mathrm{mol}$ of $\mathrm{H}_{2} \mathrm{O}_{2}$.

NADPH-oxidase activity was monitored in tissue extract made with $\mathrm{K}-\mathrm{PO}_{4}$ buffer $(\mathrm{pH}$ 7.5) containing $0.5 \%(\mathrm{~V} / \mathrm{V})$ Triton $\mathrm{X}-100$. The extract was centrifuged at $12,000 \mathrm{xg}$ for $10 \mathrm{~min}$ at $4^{\circ} \mathrm{C}$. The supernatant was used for enzyme assay in a reaction mixture containing $50 \mathrm{mM}$ Tris- $\mathrm{HCl}$ (pH 7.5), $250 \mathrm{mM}$ sucrose, $0.1 \mathrm{mM}$ NBT, $0.02 \%$ Brij-58 and $30 \mu \mathrm{g}$ protein equivalent leaf extract. The SOD activity was inhibited using $1 \mathrm{mM}$ $\mathrm{Na}$-azide and $10 \mathrm{mM} \mathrm{KCN}$. The reaction was initiated by addition of NADH $(0.1 \mathrm{mM}$ final concentration). 
The NADPH dependent $\mathrm{O}_{2}^{-}$generation activity was monitored by following the rate of NBT reduction spectrophotometrically at $530 \mathrm{~nm}$ using $€ 12.8 \mathrm{mM}^{-1}$ $\mathrm{cm}^{-1}[32]$.

\section{RESULTS}

\subsection{Catalase Activity and Protein Quantity}

The $\mathrm{H}_{2} \mathrm{O}_{2}$ scavenging activity of CAT, when examined in the leaf extracts prepared in buffer solution, a significant decline in the activity was noticed with the salt-stressed samples as compared to un-stressed one. The average decline was found to be nearly 50 to $55 \%$ of the activity recorded in control plant leaf. Irrespective of the units used for the expression of enzyme activity, either in terms of tissue fresh weight (absolute activity) or on the basis of protein quantity (specific activity), the extent of decline was comparable (Figure 1). In assenting with spectrophotometric analysis (Figure 1), the in-gel activity assay also showed a significant low level of CAT activity in salt-treated samples (Figure 2(a)). The CAT protein quantity as visualized with western blot analysis (Figure 2(b)), suggested that under salt-stress condition although the CAT activity is significantly reduced, the CAT protein quantity per unit of leaf protein largely remained unaffected.

\subsection{Cellular Level of $\mathrm{H}_{2} \mathrm{O}_{2}$ and NADPH-Oxidase Activity}

In plants, the decline in catalase activity is accompanied with a significant increase in cellular level of $\mathrm{H}_{2} \mathrm{O}_{2}[1$, 13]. However, our experimental results in rice plant showed a parallel relationship between catalase activity and the cellular $\mathrm{H}_{2} \mathrm{O}_{2}$ concentration. In salt-stressed leaves, concomitant with decline in enzyme activity there was also a decline in the level of $\mathrm{H}_{2} \mathrm{O}_{2}$ (Figure 3). Compared to control leaf, nearly 25-35\% low concentration of cellular $\mathrm{H}_{2} \mathrm{O}_{2}$ was evident in salt-stressed leaves.

The intrinsic $\mathrm{H}_{2} \mathrm{O}_{2}$ formation rate in the leaf tissues of salt-stressed and un-stressed plants were evaluated by measuring NADPH-oxidase activity as a representative of oxidase enzymes, responsible for generating $\mathrm{O}_{2}{ }^{-}$in the cell (Figure 4) that eventually is translated to $\mathrm{H}_{2} \mathrm{O}_{2}$. The enzyme was found to maintain nearly a 1.5 fold high activity in leaves of salt-stressed plants than the un-stressed one, suggesting that salt-stress induces a higher formation of $\mathrm{H}_{2} \mathrm{O}_{2}$ in the leaf tissue.

\subsection{Effect of Osmolytes on the Catalatic Activity of CAT}

We made an attempt to find out the effect of the osmolytes like sorbitol, mannitol and also sucrose on the $\mathrm{H}_{2} \mathrm{O}_{2}$ scavenging activity of the CAT in the extracts made from leaves of both control and salt-stressed rice plant.

To achieve this end, the extraction and enzyme assay

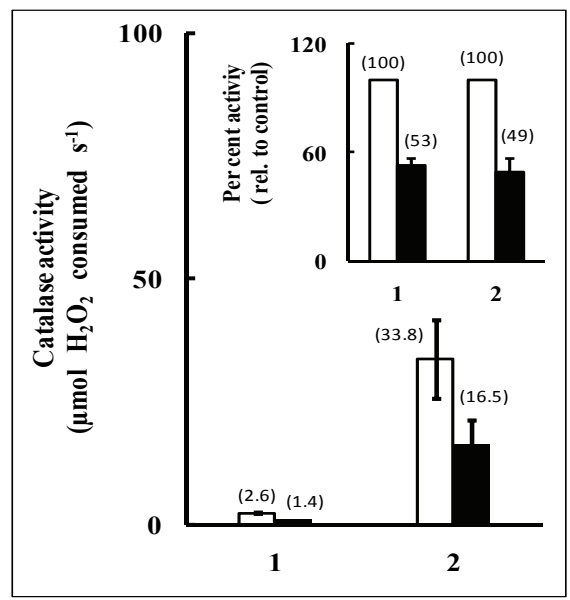

Figure 1. Hydrogen peroxide scavenging activity of catalase in crude leaf extracts of control (open bar) and 300 $\mathrm{mM} \mathrm{NaCl}$ stressed (solid bar) rice plant. The enzyme activity was measured in $50 \mathrm{mM} \mathrm{K}-\mathrm{PO}_{4}$ buffer ( $\left.\mathrm{pH} 7.5\right)$ containing $24 \mathrm{mM} \mathrm{H}_{2} \mathrm{O}_{2}$ (final concentration) and the leaf extract $30 \mu \mathrm{g}$ protein equivalent protein extracts. The rate of enzyme activity is expressed both in terms of unit protein (specific activity, 1), and leaf fresh mass (absolute activity, 2). The inset depicts the per cent loss in CAT activity in salt-stressed leaf relative to activity of control leaf taken as $100 \%$. Vertical bars represent the \pm SD $(n=13)$. The respective values of enzyme activity have been shown in bracketed numbers.

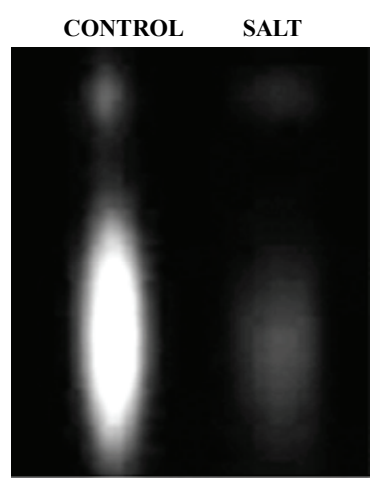

(a)

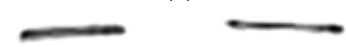

(b)

Figure 2. (a) In-gel catalase activity assay of crude protein extracts from the leaves of control (CONTROL) and salt treated (SALT) rice plant. The quantity of crude protein loaded from each of the respective preparations was $30 \mu \mathrm{g}$; (b) shows the rice CAT-antibody reactivity in the crude leaf protein extract separated in SDS-PAGE.

medium was supplemented with varied concentrations of the osmolytes. Inclusion of osmolytes in both extraction and assay medium significantly enhanced the activity (Figure 5). The stimulation was registered to be an os- 


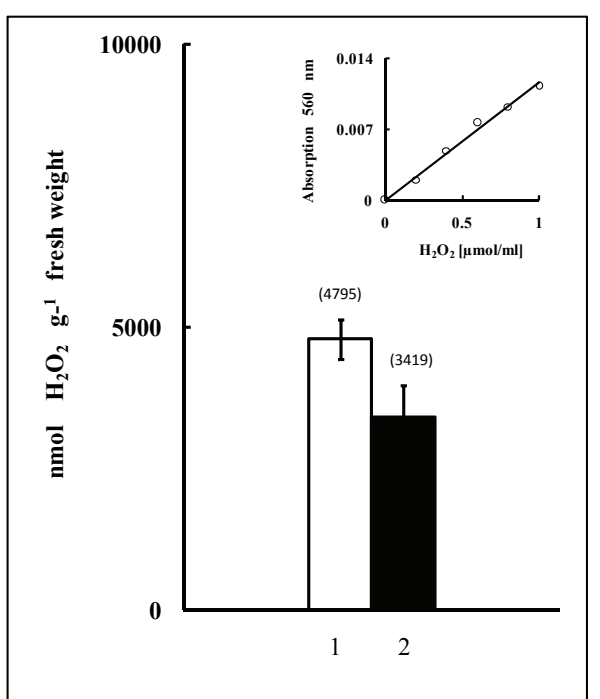

Figure 3. Comparison of steady state level of leaf tissue $\mathrm{H}_{2} \mathrm{O}_{2}$ in control (1) and salt-stressed (2) rice plant. The data points represent the mean of 7 independent experimental observations and the variation in the quantity from mean value has been depicted as \pm SD in form of vertical bars. The inset depicts the sensitivity of the methodology in $\mu$ mol range of $\mathrm{H}_{2} \mathrm{O}_{2}$.

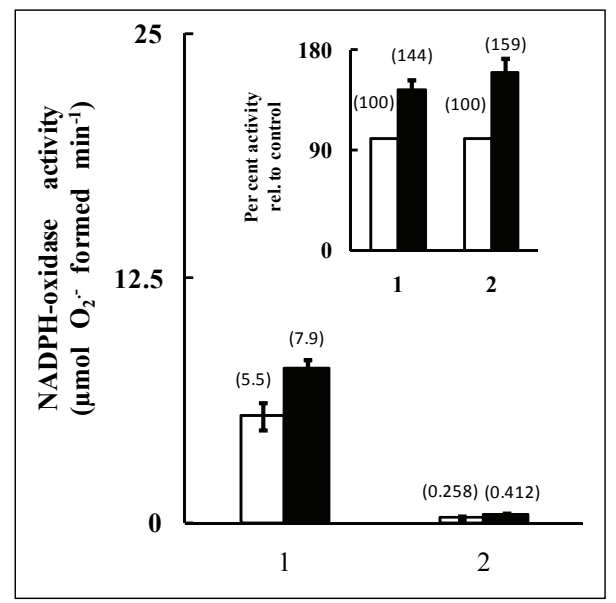

Figure 4. NADPH-oxidase activity in crude leaf extracts from control (open bar) and $300 \mathrm{mM} \mathrm{NaCl}$ stressed (solid bar) rice plant. The enzyme activity was expressed both in terms of unit leaf fresh weight (absolute activity, 1) and per unit protein quantity (specific activity, 2). The inset depicts the per cent increase in enzyme activity in salt-stressed leaf relative to activity of control leaf taken as $100 \%$. The respective values of activity have been shown in bracketed numbers, averaged from 5 independent observations with \pm SD shown as vertical bars.

molyte concentration dependent phenomenon. Maximum stimulation was visualized in the range of $300-500$ $\mathrm{mM}$ with sugar alcohols and between 200-300 mM with sucrose. Excesses of sucrose beyond $300 \mathrm{mM}$ induced a decline in activity. While a comparable stimulation in activity was discernible with sugar alcohols like sorbitol and mannitol, a significant higher stimulation was achieved by inclusion of sucrose in the medium.

\subsection{In Vitro Susceptibility of Catalase Activity to $\mathrm{NaCl}$}

Susceptibility of catalase activity to exogenously added salt was examined by incubating the crude extracts prepared from control and salt-stressed rice plant leaves with $150 \mathrm{mM} \mathrm{NaCl}$. The effect of osmoticum was also evaluated in this preparation. Incubation with $\mathrm{NaCl}$ diminished the CAT activity in a time dependent manner in control-extract made and assayed only in buffer solution (data not shown). Nearly $70-75 \%$ of original activity present in the extract made before the addition of salt was inhibited at the end of 2-h of salt incubation. However, in preparations and measurements made in presence of osmolytes, this decline was appreciably reduced. At 2-h of salt-incubation, the decline was noted to be 27, 37 and 18 percent with mannitol, sorbitol and sucrose respectively (Figure 6). Contrary to this observation, a marginal (3-4\%) enhancement in CAT activity was marked in salt-stressed leaf extract prepared in presence of osmolytes (data not shown).

\subsection{Glycolate Oxidase Activity}

Glycolate oxidase showed nearly a 1.5 fold increased activity in extracts made from leaves of salt-stressed plant as compared control activity (un-stressed). The salt-induced stimulation in GO activity was fall back to the level of control activity on inclusion of sucrose in the extraction and assay medium (Figure 7).

\section{DISCUSSION AND CONCLUSION}

The response of CAT activity to salt-stress in salt sensitive plants has frequently been contradictory. Majority of reports suggest a salt-induced down regulation of its activity [13]. Although the rice plant used in the present investigation showed a declined enzyme activity under salt-stress as compared to control plant, the protein level was found to remain almost identical (Figures 1, 2(a) and 2(b)). The reduction in CAT activity was also accompanied with a low level of $\mathrm{H}_{2} \mathrm{O}_{2}$ in salt-treated plants than control (Figure 3). Diverse methodologies have been employed by different workers to quantify the $\mathrm{H}_{2} \mathrm{O}_{2}$ level in varieties of plant tissues [7,33]. The Fox-1 method having $\mathrm{H}_{2} \mathrm{O}_{2}$ detection sensitivity as low as 0.2 $\mu \mathrm{mol}$ has been employed in our investigation (Figure 3 inset). Contradictory to reported results, instead of an inverse relation between $\mathrm{H}_{2} \mathrm{O}_{2}$ level and CAT activity, our results showed a direct relationship between them (Figure 1 and Figure 3). Appearance of a direct relationship between the CAT activity and the steady state level of cellular peroxide content in rice plant used in this investigation may be explained by arguing that un- 
der low activity of CAT, the plant uses other $\mathrm{H}_{2} \mathrm{O}_{2}$ scavenging enzymes like POX and APOX as the major scavenger of the peroxide. However, this is very unlike because of the limitation of the sensitivity of these enzymes to the substrate, $\mathrm{H}_{2} \mathrm{O}_{2}$. As compared to CAT, the activities of these enzymes are known to be saturated at substantially low concentration of $\mathrm{H}_{2} \mathrm{O}_{2}$ [17]. Further, the measurement of steady state level of $\mathrm{H}_{2} \mathrm{O}_{2}$ does not signify the actual quantity of the peroxide formed in the system, since the protocol involves the quantification of the residual peroxide following its removal by the antioxidant enzyme(s). Therefore, we evaluated the catalatic rate of one of the major enzyme engaged in formation of $\mathrm{H}_{2} \mathrm{O}_{2}$; the NADPH-oxidase. The enzyme showed nearly 1.5 fold enhanced activity in salt-stressed leaf compared to control (Figure 4). In addition to NADPH-oxidase, the high catalatic activity of glycolate oxidase in salt-stressed leaves also indicate a higher formation of $\mathrm{H}_{2} \mathrm{O}_{2}$ due to salt-induced enhanced photorespiratory activity of the plant (Figure 7). These results suggest that the salt-stress indeed induces a high level of $\mathrm{H}_{2} \mathrm{O}_{2}$ generation in control rice plant leaf but due an efficient scavenging system the cellular concentration of the peroxide is maintained at a lower level than the control.

Salt-stress induced synthesis of low molecular weight metabolites of varied chemical constituents having compatibility with cell cytoplasm is a wide spread response in diverse range of organisms [25]. These metabolites although have been implicated as osmo-regulators, they are also engaged as osmo-protectants in maintaining protein function by protecting them against salt-induced damages [25]. Hence, the in vivo milieu available for the enzyme catalysis in salt-stressed and un-stressed plants is different in terms of their osmo-molarity, salt concentration, and also the redox conditions; prevailing in the cell. Therefore, the observed decline in CAT activity (Figure 1) may have been an apparent reflection due to non-availability of in vivo milieu for achieving its maximal catalatic activity under cell free condition, when extracted and assayed using only buffer solution (Figure 1). This assumption was found to be true since inclusion of mannitol, sorbitol or sucrose in extraction and assay medium enhances the catalatic activity of the enzyme in salt-stressed plant that exceeded by nearly 1.5 to 1.8 fold higher than the activity obtained in unstressed plants. These results imply that under salt-stress environment the observed decline in CAT activity, measured without applying the probable in vivo conditions of osmotic milieu results in an apparent observation than in real. Thus our observation on low steady state level of $\mathrm{H}_{2} \mathrm{O}_{2}$ in salt-stressed rice plant (Figure 3) can now be explained on the basis that the in vivo activity of the CAT enzyme is much higher than the unstressed plant and thereby a greater extent of scavenging activity of the enzyme maintains a reduced level of the peroxide in the cell.

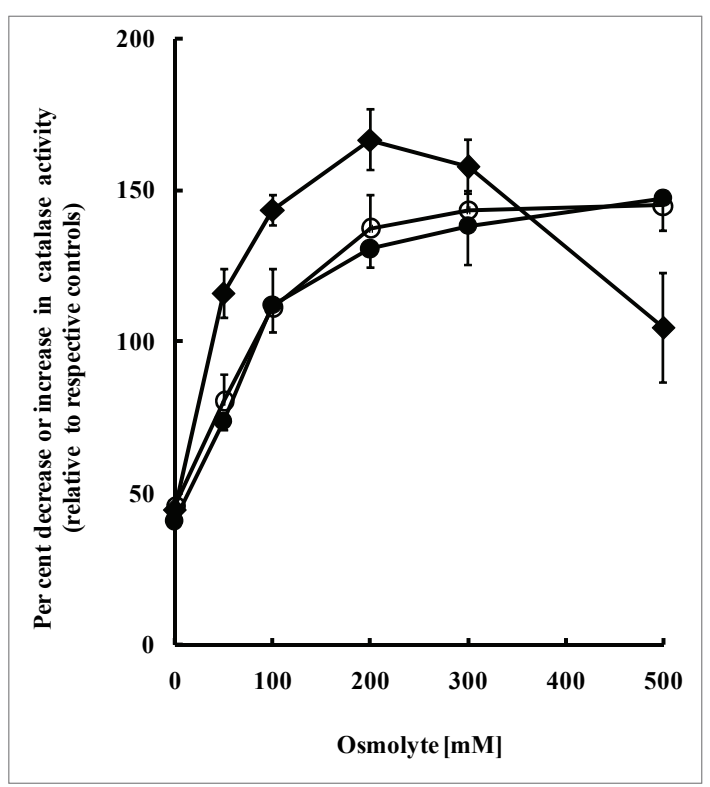

Figure 5. Osmolyte concentration dependent relative stimulation in CAT activity in leaf extract from salt-stressed rice plant. The relative activities were determined taking the control CAT activity as $100 \%$, at each of the osmolyte concentration considered under identical extraction and assay protocol. The symbol denoting closed circle, open circle and closed triangle refers respectively to CAT activity in presence of mannitol, sorbitol and sucrose. The data points are the average of 5 independent experiments with $\pm \mathrm{SD}$ shown as vertical bars.

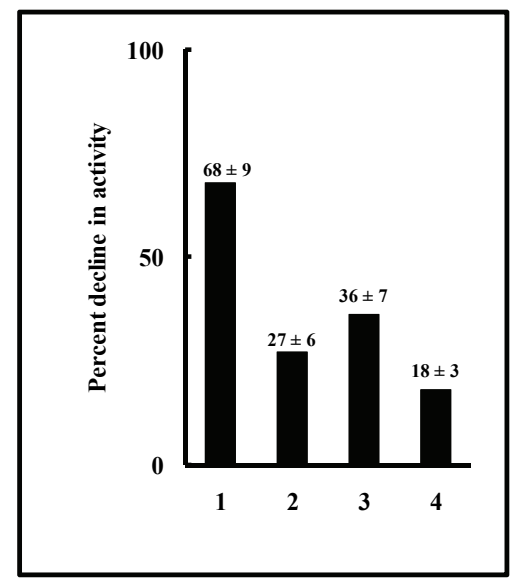

Figure 6. Decline in control plant leaf CAT activity in crude extract during 2-h in vitro incubation with $150 \mathrm{mM}$ $\mathrm{NaCl}$ in absence (1) and presence of osmolytes like, 500 $\mathrm{mM}$ mannitol (2), $500 \mathrm{mM}$ sorbitol (3) and $300 \mathrm{mM}$ sucrose (4). The results have been shown as their respective inhibition percentage taking the respective control activities as $100 \%$. The inhibition percentage are shown in bracketed numbers with the $\pm \mathrm{SD}(n=5)$.

The relative accumulation of various osmolytes belonging to different chemical categories like carbohy 


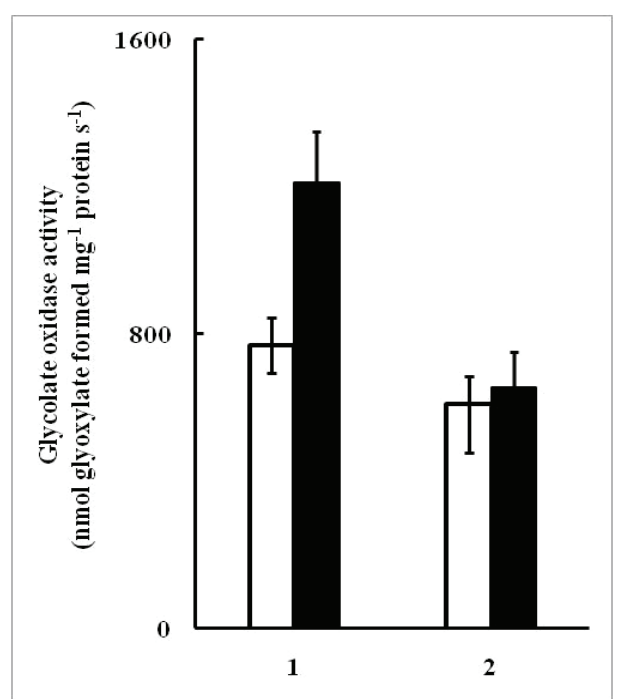

Figure 7. Histogram showing the glycolate oxidase activity of rice leaf extracts prepared and assayed from control (open bar) and $300 \mathrm{mM}$ salt-treated (solid bar) either in absence (1) and presence (2) of $300 \mathrm{mM}$ sucrose. The vertical bars represent the $\pm \mathrm{SD}$ of six independent experiments.

drates, amino acids, organic acids and sugar alcohols in rice plant on imposition of $\mathrm{NaCl}$-stress has been worked out [34]. Among the various osmolytes identified, the sucrose synthesis is significantly higher $(600-700 \mu \mathrm{g} 100$ $\mathrm{mg}^{-1}$ fresh mass) compared to other simple carbohydrates and sugar alcohols like mannitol and sorbitol (0.20-160 $\mu \mathrm{g} 100 \mathrm{mg}^{-1}$ fresh mass). Our investigation indicates that compared to mannitol or sorbitol, sucrose is superior in arresting salt-induced decline in CAT activity. This carbohydrate besides its osmo-regulatory role in tissue, has also been shown in vitrocally to render protection against unfolding of creatine kinase [35], thus maintaining the adequate rate of enzyme catalysis and stabilizing the secondary and tertiary confirmation of protein. Presently we have no experimental results to argue that $\mathrm{NaCl}$ per se can act as a denaturant in purified catalase plant protein and the effective role of sucrose in arresting the same. However, from our in vitro time kinetics results of salt-effect, it is suggested that $\mathrm{NaCl}$ per se can be a potent inhibitor of CAT activity in crude leaf extract prepared from unstressed but not in salt-stressed rice plant and the inhibition can maximally be retarded in presence of sucrose followed by sorbitol and mannitol respectively (Figure 5). Sodium chloride induced decline in CAT activity has also been reported in partially purified CAT from Phaseolus vulgaris and Medicago sativa [36].

Catalase activity in rice plant leaf, under salt-stress is found to be regulated by osmolytes (maximally with sucrose as shown here). The interaction of osmolytes induces a stimulatory characteristic to CAT, thus in- creasing its $\mathrm{H}_{2} \mathrm{O}_{2}$ scavenging efficiency more than the control plant enzyme. The underlying mechanism in osmolyte mediated elevation in CAT activity, specifically under salt-stress condition is further to be understood. In our investigation it is also clearly established that osmolyte acts preferably with the major $\mathrm{H}_{2} \mathrm{O}_{2}$ scavenging enzyme, the CAT with marginal stimulatory effects on other $\mathrm{H}_{2} \mathrm{O}_{2}$ liberating enzyme like GO. Further, the presence of low level of stimulation in CAT activity by the osmo-protectants in leaf extracts from control plants suggest that the osmolytes alone may not be the sole candidate in instituting this stimulatory effect in salt-stressed leaves. The stimulation by osmolytes may be a co-ordinated effect of participation of other cellular protein factor (s) synthesized in the salt-stressed plants. The exact nature of the compound and the under lying mechanism of co-ordinated action in bringing stimulatory effect of CAT activity remains to be deciphered. The basis for appearance of differential interaction of the osmolyte with different enzyme proteins is not known to us at present. However, our investigation also brings a major alert for choice of an appropriate protocol to measure the CAT activity in salt-stressed rice plant so as to obtain the real intrinsic catalatic efficiency of the enzyme.

\section{ACKNOWLEDGEMENTS}

Grateful acknowledgement is due to the financial help received from UGC in form of JRF to MR. Thanks are due to the Director, Institute of Life Sciences, Bhubaneswar.

\section{REFERENCES}

[1] Nor'aini, M.F., Robert, P.F. and Roy, H.B. (1997) Salinity, oxidative stress and antioxidant responses in shoot cultures of rice. Journal of Experimental Botany, 48, 325-331.

[2] Hernánde, J.A., Ferrer, M.A., Jiménez, A., Barceló, A.R. and Sevilla, F. (2001) Antioxidant systems and $\mathrm{O}_{2}{ }^{-} / \mathrm{H}_{2} \mathrm{O}_{2}$ production in the apoplast of pea leaves, its relation with salt-induced necrotic lesions in minor veins. Plant Physiology, 127, 817-831.

[3] Foyer, C.H. and Noctor, G. (2003) Redox sensing and signalling associated with reactive oxygen in chloroplasts, peroxisomes and mitochondria. Physiologia Plantarum, 119, 355-364.

[4] Mittler, R. (2002) Oxidative stress, antioxidants, and stress tolerance. Trends in Plant Science, 7, 405-410.

[5] Arora, A., Sairam, R.K. and Srivastava, G.C. (2002) Oxidative stress and antioxidant system in plants. Current Science, 82, 1227-1238.

[6] Scandalios, J.G. (2005) Oxidative stress: molecular perception and transduction of signal triggering antioxidant gene defenses. Brazilian Journal of Medical and Bio- 
logical Research, 38, 995-1014.

[7] Cheeseman, J.M. (2006) Hydrogen peroxide concentration in natural conditions. Journal of Experimental Botany, 67, 2435-2444.

[8] Shim, I.S., Naruse, Y., Kim, Y.H., Kobayashi, K. and Usui, K. (1999) Scavenging activity of NaCl-induced activated oxygen in two rice (Oryza sativa L.) cultivars differing in salt tolerance. Japanese Journal of Tropical Agriculture, 43, 32-41.

[9] Tanaka, Y., Hibino, T., Hayashi, Y., Tanaka, A., Kishitani, S., Takabe, T., Yokota, S. and Takabe, T. (1999) Salt tolerance of transgenic rice over expressing yeast mitochondrial Mn-SOD in chloroplasts. Plant Science, 148, 131-138.

[10] Foyer, C.H. and Noctor, G. (2000) Oxygen processing in photosynthesis: regulation and signaling. New Phytologist, 146, 359-388.

[11] Lee, D.H., Kim, Y.S. and Lee, C.B. (2001) The inductive responses of the antioxidant enzymes by salt stress in the rice (Oryza sativa L.). Journal of Plant Physiology, 158, 735-745.

[12] Shim, I.S., Momose, Y., Yamamoto, A., Kim, D.W. and Usui, K. (2003) Inhibition of catalase activity by oxidative stress and its relationship to salicylic acid accumulation in plants. Plant Growth Regulation, 39, 285-292.

[13] Cavlcanti, F.R., Oliveira, J.T.A., Martins-Miranda, A.S., Viegas, R.M. and Silveria, J.A.G. (2004) Superoxide dismutase, catalase and peroxidase activities do not confer protection against oxidative damage in salt-stress cowpea leaves. New Phytologist, 163, 563-571.

[14] Demiral, T. and Türkan, I. (2004) Does exogenous glycinebetaine affect antioxidative system of rice seedlings under $\mathrm{NaCl}$ treatment? Journal of Plant Physiol, 161, 1089-1100.

[15] Wingler, A., Lea, P.J., Quick, W.P. and Leegood, R.C. (2000) Photorespiration: metabolic pathways and their role in stress protection. Philosophical Transactions of the Royal Society London, 355, 1517-1529.

[16] Lo'pez-Huertas, E., Charlton, W.L., Johnson, B., Graham, I.A. and Baker, A. (2000) Stress induces peroxisome biogenesis genes. The EMBO Journal, 19, 6770-6777.

[17] Willekens, H., Chamnongpol, S., Davey, M., Schraudner, M., Langebartels, C., Van Montagu, M., Inze, D. and Van Camp, W. (1997) Catalase is a sink for $\mathrm{H}_{2} \mathrm{O}_{2}$ and is indispensable for stress defense in $\mathrm{C}_{3}$ plants. The $E M B O$ Journal, 16, 4806-4816.

[18] Rathinasabapathi, B. (2000) Metabolic engineering for stress tolerance: installing osmo-protectant synthesis pathways. Annals of Botany, 86, 709-716.

[19] Hussain T.M., Chandrasekhar, T., Hazara, M., Sultan, Z., Saleh B.K. and Gopal, G.R. (2008) Recent advances in salt stress biology - a review. Biotechnology and Molecular Biology Review, 3, 8-13.
[20] Bajaj, S. and Mohanty, A. (2005) Recent advances in rice biotechnology-towards genetically superior transgenic rice. Plant Biotechnology Journal, 3, 275-307.

[21] Kalefetoglu, T. and Ekmekci, Y. (2005) The effect of drought on plants tolerance mechanisms. Journal of Science, 18, 723-740.

[22] Tarczynaki, M.C., Richard, G.J. and Bohnert, H.J. (1993) Stress protection of transgenic tobacco by production of osmolyte mannitol. Science, 259, 508-510.

[23] Garg, A.K., Kim, J.-K., Owens, T.G., Ranwala, A.P., Choi, Y.D., Kochian, L.V. and Wu R.J. (2002) Trehalose accumulation in rice plants confers high tolerance levels to different abiotic stresses. Proceedings of National Academy Science, USA, 99, 15898-15903.

[24] Dastidar, K.G., Maitra, S., Goswami, L., Roy, D., Das, K. P. and Lahiri Majumder, A. (2006) An insight into the molecular basis of salt tolerance of L-myo-inositol 1-P synthase (PcINO1) from Porteresia coarctata (Roxb.) Tateoka, a halophytic wild rice. Plant Physiology, 140, 1279-1296.

[25] Burg, M.B. and Ferraris, J.D. (2008) Intracellular organic osmolytes: function and regulation. Journal of Biological Chemistry, 283, 7309-7313.

[26] Yoshida, S., Forno, D.A., Cock, J.H. and Gomez, K. (1976) Laboratory manual for physiological studies of rice. 3rd Edition, the International Rice Research Institute, Los Banos.

[27] Aebi, H. (1984) Catalase in Vitro. In Packer, L., (Ed.), Methods in Enzymology, Academic Press, San Diego, 105, 121-126.

[28] Woodbury, W., Spenser, A.K. and Stahmann, M.A. (1971) An improved procedure using ferricyanide for detecting catalase isoenzymes. Analytical Biochemistry, 44, 301305.

[29] Bradford, M.M. (1976) A rapid and sensitive method for the quantitation of microgram quantities of protein utilizing the principle of protein-dye binding. Analitycal Biochemistry, 72, 248-254.

[30] Baker, A.L. and Tolbert, N.C. (1966) Glycolate oxidase (ferredoxin containing form). In Wood, W.A. (Ed.), Methods in Enzymology, Academic Press, New YorkLondon, 9, 339-340.

[31] Wolff, S.P. (1994) Ferrous ion oxidation in the presence of ferric ion indicator xylenol orange for measurement of hydroperoxidase. Methods in Enzymology, 233, 182-189.

[32] Yang, Y., Xu, S., An, L. and Chen, N. (2007) NADPH oxidase-dependent hydrogen peroxide production, induced by salinity stress, may be involved in regulation of total calcium in root of wheat. Journal of Plant Physiology, 164, 1429-1435.

[33] Queval, G., Hager, J., Gakie`re, B. and Noctor, G. (2008) Why are literature data for $\mathrm{H}_{2} \mathrm{O}_{2}$ contents so variable? A discussion of potential difficulties in the quantitative 
assay of leaf extracts. Journal of Experimental Botany, 59, 135-146.

[34] Garcia A.B., Engler, J.A., lyer, S., Cerats, T., Montagu, M.V. and Caplan, A.B. (1997) Effects of osmoprotectants upon $\mathrm{NaCl}$ stress in Rice. Plant Physiology, 115, 159-169.

[35] Ou, W.B., Park,Y.D. and Zhou, H.M. (2001) Molecular mechanism for osmolyte protection of creatine kinase against guanidine denaturation. Europian Journal of Biochemistry, 268, 5901-5911.

[36] Gracia, N.A.T., Iribarne, C., Palma, F. and Lluch, C. (2007) Inhibition of catalase activity from Phaseolus vulgaris and medicao sativa by sodium chloride. Plant Physiology and Biochemistrty, 45, 535-541. 